Article

\title{
(Smart) Citizens from Data Providers to Decision-Makers? The Case Study of Barcelona
}

\author{
Igor Calzada ${ }^{1,2}$ (D) \\ 1 Urban Transformations ESRC \& Future of Cities Programmes, COMPAS, University of Oxford, \\ 58 Banbury Road, Oxford OX2 6QS, UK; igor.calzada@compas.ox.ac.uk; Tel.: +44-7887-661925 \\ 2 Global Sustainable Cities, Institute for Future Cities, Faculty of Humanities and Social \\ Sciences (HASS), Technology \& Innovation Centre, University of Strathclyde, 99 George Street, \\ Glasgow G1 1RD, Scotland, UK; igor.calzada@strath.ac.uk
}

Received: 30 July 2018; Accepted: 10 September 2018; Published: 12 September 2018

\begin{abstract}
Against the backdrop of the General Data Protection Regulation (GDPR) taking effect in the European Union (EU), a debate emerged about the role of citizens and their relationship with data. European city authorities claim that (smart) citizens are as important to a successful smart city program as data and technology are, and that those citizens must be convinced of the benefits and security of such initiatives. This paper examines how the city of Barcelona is marking a transition from the conventional, hegemonic smart city approach to a new paradigm - the experimental city. Through (i) a literature review, (ii) carrying out twenty in-depth interviews with key stakeholders, and (iii) actively participating in three symposiums in Barcelona from September 2017 to March 2018, this paper elucidates how (smart) citizens are increasingly considered decision-makers rather than data providers. This paper considers (i) the implications of the technopolitics of data ownership and, as a result, (ii) the ongoing implementation of the Digital Plan 2017-2020, its three experimental strategies, and the related seven strategic initiatives. This paper concludes that, from the policy perspective, smartness may not be appealing in Barcelona, although the experimental approach has yet to be entirely established as a paradigm.
\end{abstract}

Keywords: smart citizens; experimental cities; smart cities; technopolitics; big data; Barcelona; data commons; decision-makers; policy; GDPR

\section{Introduction: Conceptual Transitions from Smart Cities to Experimental Cities}

In recent years, European city authorities started claiming that (smart) citizens are as important to a successful smart city program as data and technology, and must be convinced of the benefits and security the initiatives offer to them [1-3]. As such, the main argument of this paper is that European cities like Barcelona are already restoring privacy and empowering citizens with data through a diverse set of policies and strategies [4,5]. In doing so, Barcelona seems to be leading a new digital transformation agenda called Data Commons Barcelona [6]. This works alongside the European Union (EU)'s General Data Protection Regulation (GDPR) [7-9], which mandates the ethical use of data to protect (smart) citizens from risks inherent in new, data-intensive technologies [10-17]. Hence, this paper, through a case study of Barcelona, explores the problem of how city authorities can proactively set up policies, strategies, and initiatives to locally enhance digital rights, and give citizens more control over personal data by protecting them from discrimination, exclusion, and the erosion of their privacy $[18,19]$.

Amid the clamor for smart-city rhetoric in Europe [20-22], a deep debate about digital ethics and rights emerged in cities such as Barcelona [23,24]. Thus, the paper aims at elucidating whether Barcelona is marking a departure from the so-called smart-city paradigm [25-28] to a newly emerging 
paradigm called experimental cities [29-31]. The case study is examined through the systematic articulation and response to three operational research questions that concern (i) the existence of alternative data ownership regimes in the ongoing smart city model of Barcelona; (ii) the practical consequences of the grassroots innovation initiatives implemented so far in the city; and (iii) the searching for evidence of another experimental type of smart city.

Methodologically speaking, this paper deconstructs Barcelona's Digital Plan 2017-2020 through qualitative fieldwork research carried out from September 2017 to March 2018 [32]. The methodology is based on the mixed-method technique of triangulation via action research [33], which encompasses a deep literature review; the findings of twenty in-depth interviews with key stakeholders, following the Penta Helix framework (private sector, public sector, academia, civic society, and social entrepreneurs/activists) [34]; and result validation through participation in three key symposiums organized in Barcelona and related to the smart city renewed strategic digital agenda formulation [35].

In the EU, the debate on data privacy, transparency, and ultimately ownership is gaining momentum as the GDPR, based on codes such as "privacy by design" and "data portability", took effect in May 2018 [36]. The GDPR may directly influence how city authorities implement their data policies and strategies, and foster potential transitions to allow citizens a more active role in decision-making processes. The GDPR may have already shifted the conversations that city authorities have with smart-city solution providers, particularly in relation to their business models, monetization strategies, and their data-processing procedures. Thus, a consensus among developers, companies, and governments on the ethics of the underlying decisions in the application of digital technology of data seems to be at stake in the post-GDPR future.

With the backdrop of this regulation, on 24 January 2018 at the World Economic Forum in Davos, Angela Merkel announced [37] "data will be the raw material of the 21st Century" and then added "the question 'who owns that data?' will decide whether democracy, the participatory social model, and economic prosperity can be combined" (p. 1). This declaration comes at a time when data sovereignty is becoming increasingly important to colocation providers, and citizens' data rights in smart cities is attracting attention from many scholars and practitioners [38-42]. At the same international event, the billionaire investor and philanthropist George Soros argued that the large [43], multinational technological firms, Facebook and Google, are "obstacles to innovation and are a menace to society", subsequently adding "(the) days are numbered for the two geek giants" (p. 1). Moreover, the digital philosopher Eugeny Morozov routinely criticized the economics of these giants' data "extractivism" business models in recent years [44-46], claiming that the models lead to a world in which these kind of tech firms build addictive services to gather citizens' data with artificial intelligence (AI) and machine learning tools [47,48]. Most recently, Cambridge Analytica and Facebook were in the spotlight due to circumstances in which Facebook data may have been illegally obtained and used by the firm [49]. This episode is having enormous influence on the technopolitical debate and the critical perception of how data analytics could have been used for political purposes without the informed consent of users. Overall, this incident highlighted the idea that political parties, data analytics companies, and social media platforms view citizens and social media users as no more than data providers [50-52]. Hence, according to Acuto [53] "data availability does not immediately translate into better-informed urban management, nor fairer, greener, and more prosperous cities" (p. 165).

The GDPR is timely when considering the debate over controversies related to algorithmic disruption and fueled by big corporations, along with hegemonic rhetoric about the benefits of technocentric smart cities. Thus, a critical perspective on data ownership blended with a socially constructed and citizen-centric smart-city approach emerges as the context for this paper. Furthermore, over the last five years, certain cities, such as Barcelona, started implementing digital policy frameworks and programs intended to strategically overcome the side effects of the technodeterministic emphasis on smart cities [54-56]. So far, this emphasis meant understanding the city just from a dispassionate, scientific perspective-purely as "solutionist", predictable, replicable, linear, and normative urban machinery fed by citizens as pure user/data providers. Moreover, citizens' data are pervasively owned by private big data firms. As such, 
it becomes a mechanical entity solely governed through the market logic stemming from the public-private partnership (PPP) scheme, and occasionally and slightly including stakeholders' engagement through helix strategies such as the Triple or Quadruple Helix [34]. By contrast, and consciously in response to this technodeterministic approach [57], a critical and evolutionary transition known as experimental cities recently surfaced in cities such as Barcelona. It is characterized by initiatives encompassing (i) the awareness of the technopolitics of data for citizens [58]; (ii) potential alternative economics for city policies [39]; (iii) citizen engagement as a democratic practice [59-62]; (iv) multi-stakeholder schemes as a pervasive governance logic [34]; and (v) living lab initiatives as sites devised to design, test, and learn from social and technical innovation in real time [29,30,63-69]. This emergent amalgamation of initiatives surrounding the experimental urbanism trend regards urban transformations as inherently interdisciplinary, data-intensive, and embedded in place. However, it remains to be seen whether the top-down, hegemonic approach to the smart city is effective in transitioning to the new paradigm, which is characterized by considering (smart) citizens as decision-makers rather than data providers.

The term smart city, which became particularly hegemonic in the policy agendas of European cities, turns 26 this year. It was introduced in 1992, around the time of the historic Rio Earth Summit, and typing it into a search engine today generates more than 15 million results. Figures for the smart-city market over the last two decades are similarly impressive [70]. Persistence market research forecasts that global growth will balloon from its current $\$ 622$ billion valuation to $\$ 3.48$ trillion by 2026-a fivefold increase in only a single decade [71].

However, according to Evans et al. [29], while the hegemonic smart-city discourse has hitherto focused on "trialing technological solutions" in real cities and benefitting multinational corporations as urban actors (p. 3), the experimental cities approaches-embodied by grassroots movements, living labs, and co-operative platforms-consistently position local communities as the designers and proactive instigators of urban experiments $[23,25,26,30]$. The smart city approach is being driven by market-based urban solutions and deconstructed from many angles after recently saturating policy agendas as a concept with very little reflexivity. In response, a new smart-citizen-centric paradigm is being tested in the experimental city. This real-world urban experiment matters because it produces "a different type of city by offering novel modes of engagement, governance, and politics that both challenge and complement conventional strategies such as on-going smart city strategies" [29] (p. 9). Therefore, new techniques explored in the experimental city approach should rethink the smart city approach from the ground up [2,72]. Reframing urban development to utilize the experimental city approach seems to shift the balance of power between stakeholders, empowering some while disempowering others, and enables new forms of co-produced knowledge by raising a fundamental academic debate around two normative questions in the smart city field inspired by Kitchin [73]: "First, for whom and for what purpose are smart cities being developed? Second, are the primary goals of smart cities about, or should they be about, (i) creating new markets and profit; (ii) facilitating state control and regulation; or (iii) improving quality of life while enhancing citizens' opportunities to participate in democracy?" (p. 7).

Hence, this paper systematically presents some key concepts. Table 1 introduces literature sources and depicts an analytical framework for ten conceptual transitions from smart cities to experimental cities as follows: (i) (smart) citizens are considered decision-makers rather than users/data providers; (ii) data sovereignty replaces "extractive big" data; (iii) cities are viewed as open platforms rather than pure markets; (iv) firms owning personal data are responsive to public scrutiny; (v) stakeholder interdependencies stemming from the social innovation perspective are implemented through the Penta Helix scheme which expands on the Triple or Quadruple Helix scheme; (vi) PPP urban business models are complemented by experimental models through urban commons and urban co-operative platforms; (vii) scalability and replication are achieved by unpacking urban problems rather than "solutionism"; (viii) the sensor network is based on a citizen-sensing awareness rather than a pure internet of things (IoT); (ix) the system is based on living-lab niche experiments rather than electronic (e)-government systems; and ( $\mathrm{x}$ ) a causality logic based on emergence and complex adaptive systems is adopted rather than a linear and normative system. 
Table 1. Conceptual transitions from smart cities to experimental cities. PPP—public-private partnership; IoT—internet of things.

\begin{tabular}{llll}
\hline \multicolumn{1}{c}{ Conceptual Transitions } & \multicolumn{1}{c}{ Smart Cities } & \multicolumn{1}{c}{ Experimental Cities } \\
\hline 1. & (Smart) citizen $[62,74-80]$ & User/data provider & Decision-maker \\
\hline 2. & Technopolitics of data $[12,24,58,81-93]$ & Big data & Data sovereignty \\
\hline 3. & Notion of the city $[94]$ & As a market & As a platform \\
\hline 4. & Personal data ownership $[41,42,49,95,96]$ & Owned by firms & Publicly scrutinized \\
\hline 5. & Stakeholder helixes $[34]$ & Triple or Quadruple Helix & Penta Helix \\
\hline 6. & Business models $[97-103]$ & PPP & Urban commons and urban co-operative platforms \\
\hline 7. & Scalability and replicability $[22,104]$ & Based on urban solutionism & Unpacking urban problems \\
\hline 8. & Algorithmic coding [105-110] & IoT sensor networks & Citizen-sensing \\
\hline 9. & Governance $[30,63,65,68,69]$ & E-government systems & Living labs \\
\hline 10. & Causality $[10,11,57]$ & Linear and normative & Complex adaptive systems and emergence \\
\hline
\end{tabular}

Since the GDPR recently took effect in the EU, the transition to data sovereignty inevitably sparked a debate regarding the role of citizens and their relationship with data in their own context. As such, two general questions frame this debate in relation to implementing the transition toward (smart)-citizen-centric, data-driven urban environments: (i) Can European cities build alternatives that put citizens back in the driver's seat as decision-makers rather than relegating them to the role of data provider? (ii) Should European cities focus on building decentralized infrastructures based on blockchain to prevent extractive data practices by large technological corporations, where these practices violate citizens' digital rights [111]? In particular, the following three operational research questions about the examination of the transition of Barcelona from the smart city to the experimental city paradigm constitute the core strands of this paper $[2,38,56,58]$ :

1. What prospects exist for an alternative data ownership regime in the current smart-city model used in Barcelona?

2. What are the practical consequences of the grassroots innovation initiatives implemented in Barcelona for businesses, local governments, academia, civic society, and social entrepreneurs/activists?

3. Is another experimental type of smart city driven by co-operative service provision models based on social innovation possible in Barcelona? That is, does a "third way" exist between the state and the market that overcomes the PPP?

To respond to these three operational research questions, the paper is organized as follows: (i) the introduction addresses the conceptual transitions from smart cities to experimental cities; (ii) a literature review on the term "smart citizens"; (iii) the results of the paper elaborate on (smart) citizens as decision-makers; (iv) Barcelona's (smart) citizens' policy framework are deconstructed through its Digital Plan 2017-2020; and (v) conclusions are presented in response to each of the three operational research questions.

\section{Literature Review}

\subsection{Conceptualizing (Smart) Citizens: A Systematic State of the Art}

Many attempts were made to conceptualize smart citizens. While a variety of researchers focused on contextually bound definitions, there seems to be a lack of agreement regarding the significance of smart citizens in practice $[40,62,74-77,112,113]$. Expanding on prior works, some authors fiercely countered the technodeterministic and/or neoliberal smart city rhetoric from policymakers and technology vendors by pointing out the absence of benefits from citizen-centered smart cities [114,115], whereas others more recently took a constructive approach to consider and elaborate upon the alternatives offered by experimentalism $[29,64,65,116]$. 
Back in 1969, Arnstein's ladder-a widespread conceptual frame used to examine citizen participation in place-making and city governance-offered a valuable heuristic to start integrating the role of (smart) citizens in the city [117]. Arnstein detailed three forms (citizen power, tokenism, and non-participation) and seven levels of participation (citizen control, delegated power, partnership, placation, consultation, informing, choice, therapy and manipulation). This conceptual framework should strongly resonate in the current European context, where the citizen's data debate coincides with the significant weakening of citizens' right to privacy and information self-determination. Likewise, a 1969 paper might provoke a profound debate on the real meaning of participation and democracy after more than 30 years of neoliberalism [40]. Despite the glossy citizen-centric institutional discourse, the framework of that paper analytically enhanced the evidence-based analysis by presenting a wide range of participation levels at which smart citizens' representation and involvement may find many modalities for deliberation. These included not participating, only consuming, providing feedback, suggesting ideas, negotiating between stakeholders with conflicting visions, and leading ownership regimes. These findings are particularly relevant when cities become expanded laboratories-with special efforts to equip (smart) citizens with information and skills to enable access beyond merely supplying data. In this way, different, sustainable, prosperous, and livable urban futures can be tested in real-time [118]. Coletta et al. [82] argue that "Singapore, Barcelona, Dublin, and San Francisco are (currently) but a few examples of cities undertaking experimental modes of development" (p. 8).

More recently, Ratti [38] argued that municipalities in these timely transitional examples "are starting to understand the importance that citizens, in particular, should have a key role through 'bottom-up' dynamics" (p. 142). Therefore, instead of concentrating on the installation and control of hardware, the (smart) citizens approach highlights the importance of governments getting people enthusiastic about creating apps and exploiting data themselves. Thus, an understanding of this novel paradigm of data-which involves algorithmic analysis of unrelated datasets within presently under-examined situations and social interactions-exists in the recent literature. It suggesting that the notion of (smart) citizens should be associated with the idea that governments, regardless of governance scale, should act as data facilitators rather than as providers of services. This notion connects directly with the aim of this paper insofar as (smart) citizens interact (often unwittingly) with an increasing volume of data, encounter pervasive and unethical extractive data practices, face an increasing number of privacy issues, and remain unaware of the value of their data in terms of ownership; addressing these issues opens new avenues to engage citizens with government digital policy and strategic frameworks through specific initiatives and projects [119].

Over the last few years, the idea of smart citizens profoundly influenced smart-city literature [40,75-80,113]. In summary, scholars such as Cardullo and Kitchin [40] interestingly argue that the concept of the smart citizen is often synonymous with "choice" in the market, with the following predominant roles: a "consumer" or "user"-who selects the services acquired from the marketplace of providers; "resident" - who can afford the exclusivity offered by a "smart district"; and "data provider" - who creates data through the use of smart-city technologies that companies can incorporate into products and extract value from. For instance, one study [40] recently revealed that citizens in smart cities are "consistent with neoliberal citizenship and its emphasis on personal autonomy and consumer choice" (p. 12). This remarkable interpretation may lead us to reflect upon individuals performing certain roles and taking responsibility for opportunities in their private life (entrepreneurial self), and for the marketization and privatization of amenities and infrastructures. Despite citizen participation being potentially varied, it is frequently framed in a post-political fashion that provides feedback, participation, negotiation, and creation within an instrumental frame - rather than a normative or political one. That is to say, citizens are stimulated to assist in providing solutions to everyday issues, for example by producing an app, giving an opinion on a progress plan, or performing certain functions/responsibilities that do not contest or substitute the fundamental political rationalities affecting an issue or plan. Very often, citizens are empowered by devices that consider them as consumers or testers-people to be steered, controlled, and nudged to behave in certain ways-or 
as raw material for algorithms that can be turned into commodities-i.e., passive data providers. In other words [40], citizens in the smart city act within the constraints of predictable and acceptable patterns "rather than transgressing or resisting social and political norms" or simply becoming active decision-makers (p. 12).

Recent literature on smart citizens reached broad consensus that technological solutions are often proposed under the sponsorship of the smart city buzzword, while neither considering citizens' needs nor socio-technical misalignment between mechanical urban solutions and the citizens' decision-making processes [56,120,121]. Moreover, the literature review of recent reports published by the European Commission, analyzing the implementation of a wide range of H2020 lighthouse projects and covering developments on smart citizens, illustrates that smart-city initiatives only foster limited forms of citizen engagement and citizen power [20-22,104]. Although some European cities are allegedly being used as experimental testbeds or living laboratories for super-connected, technologically mediated smart districts, they must continue providing common resources and benefits to all citizens. Thus, the expectations that (smart) citizens participate in these experimental laboratories should be grounded in a much more politically active discourse of rights and urban commons [102]. In other words, is it possible to reassemble the driving ethos for smart cities beyond a market rooted in data ownership?

\subsection{Deciphering the Case Study of Barcelona: (Smart) Citizenship at Stake in European Cities}

Hence, (smart) citizenship appears to be at stake. In response, European smart cities such as Barcelona [122] and Amsterdam [123] (Barcelona's partner city in EU project Decode) are leading an alternative movement by following experimental city policy framework practices that rely on democratic data ownership regimes establishing municipal data offices, grassroots innovation, and co-operative service provision models [29,63-65,124,125]. These cities are implementing pervasive transitions to cope with the disruption to the technopolitics of data, and address concerns that include privacy, literacy, awareness, and ownership issues while empowering local communities to avoid the side effects of the predatory sharing economy and extractive practices $[2,126]$.

According to Cardullo and Kitchin [40], Barcelona "is presently attempting to formulate and implement a different vision of a smart city and smart citizenship" (p. 13). While under a right-wing and neoliberal government in the early 2010s, the city became an iconic smart city through its abundant initiatives and self-promotion events within the program "Smart City Barcelona" [127]. However, since the May 2015 election of Ada Colau-the new mayor, representing the left-wing, green, social movement coalition-Barcelona gradually experimented with its vision and policy framework via the Digital Plan 2017-2020, deployed as "Barcelona Ciutat Digital: A Roadmap Toward Technological Sovereignty" [32,128]. In October 2016, the new vision for Barcelona was fixed as an "open, fair, circular, and democratic city" with a special emphasis on its mission to promote citizens' data ownership and technological sovereignty. This was a conscious strategy to overcome the excesses of data extractivism [35]. Since then, the Barcelona City Council implemented a new policy framework entitled the Barcelona Data Commons program [6], which parallels an EU-funded experimental project titled Decode $[129,130]$. The latter project functioned as a testbed and flagship project to repoliticize the smart city and shift its creation and control toward grassroots, civic movements, and social innovation, and away from private interests and the state [131-133]. As an amalgamation of strategic initiatives, the policy framework established under the Barcelona City Council Digital Plan 2017-2020 is analyzed in the fourth section of this paper.

Based on this new shift, Barcelona is currently explicitly branding itself as an inclusive, democratic, and participative smart city by promoting accordingly [1,134,135]: "If you would rather have smart citizens than smart cities ... BITS, 'Barcelona Initiative for Technological Sovereignty', will be in your interest" [35] (p. 1). Likewise, in Amsterdam, those advocating for smart citizens suggest that (smart) citizens should be guided by the following principles [78,84,121,123]: take responsibility for the environment they live and work in, and the places they like; value access over ownership 
and involvement over power; ask for tolerance, not authorization; ethical algorithms rather than extractive algorithms; and offer assistance to less technologically savvy individuals. This set of ethics underlies the notion of a still-limited consideration of the interconnections between hard and soft smart infrastructures, as well as those between political, institutional, economic, and social systems on the metropolitan and regional scales. Moreover, this new paradigm advocates the significance of overcoming the often-failed smart-city-in-a-box strategy, by keeping the loop with the various stakeholders.

By examining the Digital Plan 2017-2020 of Barcelona [32], in particular, it is evident that the notion of the commons extensively influenced the three experimental strategies of Barcelona's renewed smart city plan that were put into effect since September 2016 [136-138]. Three main strategic components were identified as experimental strategies during the fieldwork research (and are explained in greater detail in the next section): (i) a data commons through three strategic initiatives; (ii) local democracy through two intertwined grassroots innovation initiatives; and (iii) political economic co-operative platforms in relation to three initiatives built around Digital Social Innovation, Barcelona Urban Commons, and a "social economy" municipal framework. Thus, this plan may open a new path for action in Barcelona based on Ostrom's prominent thinking on the commons $[4,98,99,102]$. For example, one of the strategic initiatives, entitled Data Commons Barcelona [1,6], is defined as "a shared resource that enables citizens to contribute, access, and use the data-for instance about air quality, mobility, or health-as a common good, without intellectual property rights restrictions" (p. 1), which clearly resonates with Ostrom's assertion that nonprofit and voluntary actions should govern the collective resources that many citizens use as data (including free software, Wikipedia, and Open Street Map). However, as Hardin warned [100], the "tragedy of the commons" could occur when data extractive practices conquer the urban metabolism. A notion of the commons, recently updated by Bollier, argues that historically embedded individualization procedures gradually shape the communal settings such that they require experimental interventions as a corrective [136].

In a bold attempt to transition from a smart city to an experimental city, conceptual explorations around the commons are likely to influence a more profound examination of the technopolitics of data. Thus, because this paper emphasizes the active role of (smart) citizenship; the conception of the commons should be encompassed in the narrative, because the rhetoric of the hegemonic smart city is uniquely based on the idea of PPPs [139]. Bollier suggests that cities are at an intersection insofar as (smart) citizens could use the ideas of the commons to retain control of the services that matter to them and safeguard the functions of these services for the people of the city, and not only for businesses or bureaucracy. However, the idea of the commons could also be argued to be rather abstract with regards to policy implementation.

One possible solution to the issues above is offered by the hypothesis of this paper: the notion of (smart) citizens as decision-makers is being explicitly included in the policy formulation of Barcelona by addressing the three main operational research questions of this paper. The fieldwork research process identified three experimental strategies that directly relate to the debate on the implications of the GDPR for citizens and on the governance structures required to critically tailor the technopolitics of these data:

- Alternative data ownership alternative regime initiatives;

- Grassroots innovation initiatives;

- Co-operative service provision models, such as urban co-operative platforms [97], living-lab initiatives $[67,68,140]$, and proactive social economy policy frameworks. 
Ultimately, this paper aims to examine whether the rhetoric of the experimental city is followed by an evidence-based impact in the case of Barcelona. The exact definition of more citizen-centered approaches is often left unstated; therefore, this paper aims to unravel the meaning from the Barcelona case to provide evidence-based insights into the city's experimental strategies. Within the scope of some approaches to experimental cities, the extent to which citizens play a more active role as co-producers rather than as mere data providers remains to be seen, although the technopolitics of data (i.e., ownership and governance) is an under-explored area of research $[85,86]$.

After a rigorous literature review covering the case of Barcelona and its transition from the "Smart City Barcelona" strategic period in 2011-2014, led by former mayor Xavier Trias [141-143], to the current "Barcelona Data Commons" strategic period led by current mayor, Ada Colau, [58,79,80,127,134,135,144-147], this paper offers the hypothesis that the existing smart city cannot simply be reduced to the economic trade-off of the data it generates through partnerships with powerful public and private actors [139]. A key element of this shift in discourse is the need to embrace a multi-stakeholder approach by broadening the representation of social actors in decision-making processes in order to overcome the new religion of data. Coined "dataism" by Harari [87], over-reliance on data is understood as a logic oversimplifying a city's metabolism as a mere assemblage or system of data and algorithms [12,16,44,88,92,93,148,149], rather than an ecosystem of citizens [116].

\section{Results: Technopolitics of Data for (Smart) Citizens as Decision-Makers Rather Than Data Providers}

According to the research firm Gartner [150], 8.4 billion devices worldwide were connected to the internet by the end of 2017, and 20.4 billion are expected by 2020 . However, as previous sections in this paper highlight, some hesitation persists at the center of the dataism discussion (see the article by Harari [87]). Thus, what are the real consequences of the big data for (smart) citizens? In response to this open question, Shilton [89] argued that "uncertainties about how to use increasingly large sets of personal data are at the center of social debates about the virtues of big data". She continues "Not all 'big data' are data about people, but data about people inspire much of the hope and anxiety bound up in discussions of the term" (p. 21). Thus, who controls not only data collection, analysis, storage, and usage, but ultimately ownership? Table 2, inspired by Shilton's contribution, was elaborated to enhance the key parameters of the technopolitics of data related to the degree of citizen participation in today's cities. The interpretation by Shilton is complemented in that it can be assumed that users with high participation-smart citizens-would be able to control the reuse of their own data. This assumption is a reaction to the fast development of the data extractivist practices by which (smart) citizens should not only be involved in participation processes, but also gain the knowledge to engage autonomously in the data collection processes. It may offer to bridge the gap to implementing data sovereignty, ownership, and commons policy schemes (as the case study of Barcelona depicts).

Concerning updated sources of data collection, storage, use, and ownership, the major obstacles to fostering a people-centered design of data are found in the acquisition, shareability, licensing, and knowledge boundaries of the obtained data. Thus, the requirement to consider individuals not only as citizens deliberating on their material conditions, but also as consumers agreeing and disagreeing to the specific terms of a provision should be taken further by advocating for a more human-centered perspective to the smart city—one that fosters interplay and interdependencies among multiple stakeholders. 
Table 2. Citizen participation in the technopolitics of data collection, analysis, storage, reuse, and ownership. Based on Reference [89] (p. 26).

\begin{tabular}{|c|c|c|c|c|c|}
\hline $\begin{array}{l}\text { Citizen Participation in the } \\
\text { Technopolitics of Data }\end{array}$ & Collection & Analysis & Storage & Reuse & Ownership \\
\hline High participation & $\begin{array}{l}\text { Subjects own or control } \\
\text { devices; data collection } \\
\text { can be customized }\end{array}$ & $\begin{array}{l}\text { Raw data accessible; } \\
\text { subjects can conduct } \\
\text { their own analyses }\end{array}$ & $\begin{array}{l}\text { Data stored on } \\
\text { local devices }\end{array}$ & $\begin{array}{l}\text { Individuals } \\
\text { control reuse }\end{array}$ & $\begin{array}{l}\text { Individuals own their } \\
\text { data and customize their } \\
\text { data policy }\end{array}$ \\
\hline Low participation & $\begin{array}{l}\text { Subjects aware of } \\
\text { devices; data collection } \\
\text { can be avoided }\end{array}$ & $\begin{array}{l}\text { Subjects can see } \\
\text { visualizations or } \\
\text { analysis of their data }\end{array}$ & $\begin{array}{l}\text { Data in cloud } \\
\text { storage with } \\
\text { options for deletion }\end{array}$ & $\begin{array}{l}\text { Reuse is } \\
\text { restricted to } \\
\text { aggregated forms }\end{array}$ & $\begin{array}{l}\text { Data collectors use } \\
\text { contracts to obtain } \\
\text { citizens' consent over } \\
\text { their own data }\end{array}$ \\
\hline Little to no participation & $\begin{array}{l}\text { Subjects unaware of } \\
\text { devices; data collection } \\
\text { cannot be avoided }\end{array}$ & $\begin{array}{l}\text { Subjects are } \\
\text { evaluated or } \\
\text { categorized without } \\
\text { their knowledge }\end{array}$ & $\begin{array}{l}\text { Data in cloud } \\
\text { storage with no } \\
\text { option for deletion }\end{array}$ & $\begin{array}{l}\text { Data collectors } \\
\text { share or sell data }\end{array}$ & $\begin{array}{l}\text { Data collectors own } \\
\text { citizens' data }\end{array}$ \\
\hline
\end{tabular}

Habermas opposed technocratic and democratic smartness, enabling the generalization of the smart-citizen category [151]. Traditional notions of the smart city put individual privacy at risk, and thus, citizen interaction, involvement, engagement, participation, and deliberation are the focus of the debate on the technopolitics of data. Yet, how should we address the distrust, apathy, and open indignation that turned progressively pervasive in political attitudes? Misalignments between algorithmic computation and the social desires of citizens in data generation and ownership constitute a collective challenge facing us today: Will data-driven cities and devices continue to serve citizens or vice versa [54,90]? Is computation replacing conscious thought? Are we thinking increasingly like a machine, or are we not even thinking at all? In response to these questions, different forms of engagement on the part of (smart) citizens can be discussed in relation to the technopolitics of data and the algorithmic disruption [10,11]. Morozov argued that key questions [44], such as "who implements data?" and "what kinds of data do technological solutions smuggle through the back door?" (p. 1) remain unanswered despite the plethora of technological solutions to social problems. Policy discussions highlight how seemingly simple calls for open data strategies actually challenge existing legal norms and have potentially profound implications for users down the line. For instance, liability risks might be passed to the end user of open data, but what if the end users cannot bear those risks? If the IoT generates continuous monitoring and commonly individualized data, how do we theorize, regulate, and make visible the ethical choices that emerge around the legal liability surrounding the ownership of data [18,152]? Ownership of data promises to deliver significant personal and public benefits if city authorities start reconceiving data as a new type of common good. According to the Barcelona city authorities, (smart) citizens' data can generate public value by protecting citizens' "technological sovereignty" as a whole [1].

Hence, citizens' personal data are a fundamental part of their urban experience, and their digital rights should be based on a logic of solidarity, social co-operation, and collective rights to the city [148]. Why, then, do we not naturally consider (smart) citizens as pure decision-makers rather than simply passive data providers? Despite the willingness to pursue sustainable futures that are more democratic than technocratic futures, strong inertia obstructs this alternative path. If the government offers greater data accessibility, better public services will be delivered $[1,59,91]$. Thus, alternative policy paths explore city government policies that could require large corporations to share data collected from their users to preserve full digital rights for citizens by developing decentralized, privacy-enhancing alternative data infrastructures based on blockchain and attribute-based cryptography [111,125]. In fact, the current round of urban experimentation differs from previous incarnations [29], indicating a "specific type of governance fix for a neoliberal system that is struggling to move toward more sustainable forms of urban development" (p. 10). In Barcelona, this ongoing experimentalism addresses new business and social models that also demand previously accepted legal frames and procurement regimes be revisited. According to Francesca Bria, the Chief Technology Officer (CTO) of Barcelona [38], the technopolitics of data in Barcelona are articulated in response to an explicit strategy to "disrupt these data accumulation, making data available across vertical silos experimenting with decentralized 
data infrastructures through distributed ledgers such as blockchain, and proposing new frameworks and business models that reward and incentivize openness, enabling data discovery, transactions, and secure data sharing" (p. 145). This citizen-centric approach to the technopolitical policy scheme of Barcelona is called Barcelona Data Commons [6]; it is influenced by the experimental EU-funded project Decode [129], which is centered around strategic initiatives regarding technological sovereignty and data transparency.

This section underlines how data-driven and algorithmic issues open up novel challenges for implementing policy in cities all over the world. In terms of the ethical, institutional, and political dimensions of the ownership of data, urban experiments-Barcelona in particular-are gaining traction as a strategy to stimulate alternatives and steer change [124], as suggested by the Digital Plan 2017-2020. The idea of experimentation feeds on the appealing notions of innovation and creativity (both individual and collective) while also shifting the focus of sustainability from distant targets and government policies to concrete and feasible actions that can be undertaken by a wide variety of urban stakeholders in particular locations. The ability of urban experiments to be radical in ambition while limited in geographical scope underpins a challenging debate in both the policy and academic domains with respect to the potential for such experiments to initiate genuine transformation. Are these experiments simply extensions of business as usual, spatially limited, and captured by a familiar cast of dominant interests? Or, can they engender genuine alternatives and stimulate profound transformation?

Thus, the next section examines the case of Barcelona in depth by deconstructing the Digital Plan 2017-2020. I analyze the promises and hazards of experimentation as an alternative mode of urban governance that moves beyond the structural mistakes of the so-called smart city, which is the dominant mode thus far $[30,57]$. The section is divided into three subsections that examine the three experimental strategies of Barcelona's Digital Plan through an analysis of fieldwork material: policy documents, interviews, and symposiums (Appendix A). The first subsection examines the first operational research question presented in the introduction, situating (smart) citizens within the context of the data ownership and technological sovereignty experimental strategy; three initiatives illustrate the ways in which experimentation is occurring within Barcelona. In the second subsection, I investigate the experimental strategy of grassroots innovation in response to the paper's second operational research question; two intertwined initiatives are presented to allow dissection of the practical consequences for stakeholders (interviewed following the Penta Helix framework). In the third subsection, the paper explores the extent to which considering decision-makers could achieve a potential ecosystem of co-operative service provision models as alternatives to capital-based forms of business.

\section{Methodology and Discussion: Deconstructing Barcelona's (Smart) Citizens' Digital Policy Framework Case Study}

According to the Barcelona City Council's Digital Plan 2017-2020 [32], “in September 2016, Barcelona City Council embarked on an important digital transformation process, announcing that public services must be provided through digital channels from the outset, following new guidelines oriented toward citizens and the use of open standards and open-source software, and in accordance with an ethical data strategy that puts privacy, transparency and digital rights at the forefront" (p. 3). The smart-citizen concept at the core of this strategic formulation suggests that cities should implement new legal, economic, and governance schemes to nurture collaborative behaviors from citizens to contribute to the digital commons, including commons involving personal data. It is not yet clear the extent to which this move in strategic formulation is merely lip service to the critics of the term smart city versus an initiative that will actually lead to implementing real consideration of (smart) citizens. Thus, this section aims to provide empirical evidence-based insights to scrutinize the nature and intensity of this transition via the three operational research questions. 
To begin, the Barcelona case study will deconstruct the Digital Plan 2017-2020 by applying three methodological techniques based on triangulation. Case study research, as defined by Yin [153], was identified as the most effective form of mixed-method research. Firstly, an analysis of its most recent policy documents related to the three experimental strategies was identified in the Digital Plan 2017-2020. Secondly, a qualitative study of twenty semi-structured interviews was conducted in Barcelona from September 2017 to March 2018. The interviewees were identified following the Penta Helix multi-stakeholders' framework and included representatives from each helix (see Figure 1) [34]. The purpose of the interview study was to validate the mixed-method action-research process with a broad representation of opinions and evidence. Finally, to reinforce the mixed-method technique of triangulation via action research [33], the author participated in three symposiums directly related to the smart-city strategic formulation in Barcelona during the fieldwork timeframe (September 2017-March 2018): (i) the celebration of the Smart City Expo World Congress 2017; (ii) the ESADE Business School Smart Cities and Data Speaker Series; and (iii) a presentation of the Barcelona Data Commons program in January 2018 (see Appendix A).

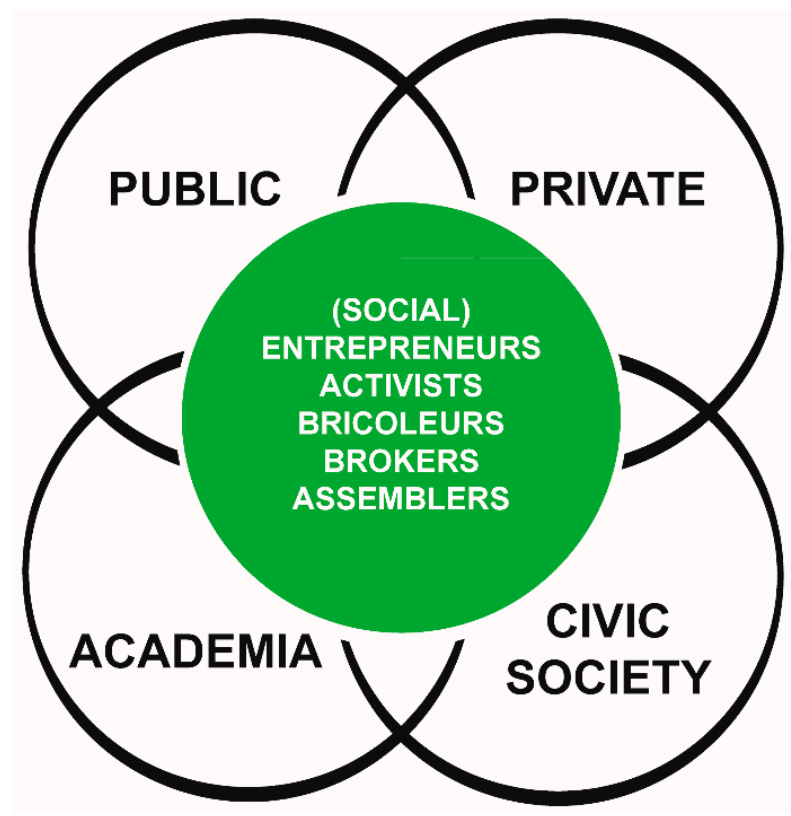

Figure 1. Penta Helix multi-stakeholders' framework [34].

The case of Barcelona was selected using a theoretical sampling approach. With slightly more than 3.2 million citizens in the metropolitan area, the city of Barcelona falls into the category of urban areas experiencing a deep transition connected to the dynamic devolution debate and vibrant bottom-up initiatives. Furthermore, its success in the smart-cities field makes the analysis of its strategic transition an ideal sample for this study; this assertion is easily demonstrated by considering the multiple smart-city awards Barcelona received, in addition to its geographical location [20].

Barcelona's smart-city strategy experienced two distinct periods. In 2011, the mayor, Xavier Trias, and his municipal administration decided to transform Barcelona into a smart city through an approach slightly biased toward top-down management and with a focus on technological capacity. However, since Ada Colau's election as mayor in May 2015, the strategy reached a clear turning point. In October 2016, the publication of "Barcelona Ciutat Digital: A Roadmap Toward Technological Sovereignty" kicked off the implementation of the new smart-citizen policy framework disseminated through the Barcelona Initiative for Technological Sovereignty (BITS) by Commissioner Francesca Bria $[1,35,128]$.

In the extensive evaluation of the literature discussing Barcelona, considerable consensus can be found regarding the strategic shift in the smart-city pathway [38,58,79,80,122,127,134,135,141-147]. Firstly, during the 2011-2014 period and based on the corporative technocratic vendor push, 
the Barcelona Smart City strategy was driven more by deliberate components than by emergent and experimental components. Secondly, the current transition, called Technological Sovereignty, gained momentum. Almirall et al. [38] highlight "tensions in smart cities regarding efforts in the provision of services" during the current period (p. 152), while Bakici et al. [141] identify five components (smart districts, living-lab initiatives, infrastructures, new services for the citizen, and open data) that are clearly being updated with the recent launch of the City Data Analytics Office. Overall, this period is characterized by a critical and proactive social context formed through transversal initiatives that merge distinct municipal datasets.

Regarding the political economy resulting from the increasing influence of grassroots initiatives on the city, Eizaguirre and Parés [144], and Degen and García [142] studied several neighborhoods in Barcelona. They found great significance in the role of collective leadership practices, creative social strategies, and political dissent in the founding and the social impact of local initiatives. Likewise, Almirall and Wareham [68], Gascó-Hernandez [143], and Timeus and Gascó [147] examined the degree of efficiency in living labs in Barcelona at different periods $[63,65,67,94,140]$. Although the findings are primarily related to public and private organizations, they suggest that it may be worth exploring the contribution of living labs as intermediaries that mediate between multiple stakeholders in highly political environments such as Barcelona [34].

For several authors, the changing urban governance model over the two periods became the most important factor in Barcelona. At the time of the switch between the two institutional periods, Capdevilla and Zarlenga suggested a combined approach by merging top-down and bottom-up dynamics [79]. This approach is already included in the political agenda of the current smart-city strategy, despite the problematic so-called smart contradictions noted by March and Ribera-Fumaz [127]: "it is unclear now how interests of citizens are to be made compatible with the interests of private capital and of the urban political elites in Barcelona" (p. 825). Their underlying critique relies on the idea that there is little exploration of the inner contradictions in how smart interventions are inserted into a wider political economy of urban transformation. As such, in this section, I pay special attention to the central role (smart) citizens hypothetically play in the collective production and administration of the city, by identifying three experimental strategies included in the Digital Plan 2017-2020.

\subsection{Establishing the Data Commons Barcelona Program, Launching the City Data Analytics Office, and Experimenting with Decode—the EU's Scientific Flagship}

My fieldwork revealed that the data ownership and technological sovereignty experimental strategies comprise three intertwined initiatives [32].

The first initiative, Data Commons Barcelona, focuses on ethical data ownership and technological sovereignty principles achieved by opening the public procurement process, and ensuring that $70 \%$ of investments in new software development go toward free and open-source software in municipal systems. Barcelona is attempting to include small and medium-sized enterprises (SMEs) in the public procurement process, generating a virtuous cycle where any SME, co-operative, or self-employed citizen can work under equal conditions while avoiding vendor lock-in and path dependency. Interviews revealed that the procurement process is opening promising pathways, based on the upcoming creation of an open digital marketplace for small-scale providers designed to meet the needs of the 13,000 existing technological companies, and to offer employment increases of $26.3 \%$ in the digital sector compared to 2016 (\#I20) (See Appendix A). This initiative is implementing services such as a help for new citizens and an information portal, mobile phone services for citizens, a new calendar of city events and facilities, an open city dashboard for citizens, a technology-provider portal, and a new mobile digital identity service. Likewise, a main principle of the technopolitics of data involves explicitly improving access to the authority's data, respecting privacy, and evaluating the ethical risks of smart cities and large databases by establishing a code of ethical technological practices, including legal compliance with data protection regulations and defining a data strategy. 
Thus, Barcelona is experimenting with socializing previously collected data via sensors operated by citizens, with the city taking the lead in aggregating and acting upon such data to promote new co-operative approaches that solve common urban issues, such as tackling noise levels and improving air quality. The plan is to keep this common data infrastructure open to local companies, co-operative platforms, and social organizations, allowing them to build data-driven services and create long-term public value [1] (\#I4). The strategy is leading the transition to the GDPR by motivating initiatives creating a data commons that incorporates self-determination and the digital right of citizens to use municipal data for the public good of all citizens and stakeholders [6] (\#I7,\#I8,\#I9,\#I11,\#I14).

Secondly, the city council opened the City Data Analytics Office on 13 February 2018. The office houses a Chief Data Officer and 40 staff members from different departments. They offer new privacy-related data improvement and analysis capabilities and can make predictions covering all areas related to managing the city. My research revealed that civil servants seem to understand the challenge of breaking down data "silos" (energy, noise, housing, garbage, meteorological, parking, air quality, water, bicycle flow, people flow, vehicle flow, and gentrification, among others) to manage three million data records per day. Despite that, it remains to be seen whether the external agile entrepreneurial culture and the bureaucratic public culture will find common ground [154] (\#I5,\#I6,\#I18). Furthermore, the new office created an Open Data Challenge program [119] to include SMEs in solving the city's challenges and to successfully position the Data Protection Delegate in line with the GDPR. The Data Protection Delegate is in charge of coordinating data protection policy within and across departments.

Thirdly, the Decode project is an EU-funded experimental project led by Barcelona (in partnership with Amsterdam) to develop a blockchain-based architecture for data sovereignty in parallel with the operational activity of the city council. It is attempting to build new foundations for data sharing on the internet, drawing inspiration from decentralized technologies such as Bitcoin, Blockstack, and Sovrin. The project enables a system whereby all interactions involving any citizen's data are fully auditable on a public ledger (though raw data itself remains hidden). Decode is testing how people could allow their data to be used for specific social purposes, such as informing local policymaking, and could overcome the municipalities' failure to foster local alternatives to certain services (such as Uber and Airbnb) due to the lack of raw data [130]. However, interviews revealed that, despite this remarkable, cutting-edge initiative, citizens and even some stakeholders currently believe that the initiative is too abstract and experimental, and question the feasibility of business models based on this scheme (\#I1,\#I2,\#I3,\#I15).

To summarize this subsection, the fieldwork research revealed that Barcelona is motivated by compliance with EU legislation, particularly the GDPR. Business models that rely on the collection and commercial exploitation of personal data based on neoliberal data extractivist practices will face clear boundaries. GDPR seems to offer to Barcelona a way to build alternative digital infrastructures that enhance privacy and can guarantee data sovereignty for citizens, giving them back control over their data. Data Commons Barcelona could be seen as a custodian of the digital rights of citizens and a milestone in the strategic formulation of Barcelona stemming from GDPR, since it is based on remarkable principles such as privacy by design, data portability, and the right to be forgotten or "unplugged" [56]. The city authorities proactively advocate application of the GDPR. For them, "it represents an opportunity to create a city data infrastructure that puts citizens' right to data at the center of the game" (\#I4). Another interviewee described the situation as follows: "We have created a new City Data Analytics Office, appointed a Chief Data Officer, and introduced a new data directive that is implemented across city hall that includes transparency, ethics, security, and privacy as fundamental principles" (\#I7,\#I8). Moreover, other interviewees representing the private sector, academia and (social) entrepreneurship/activism agree upon the following visionary statement (\#I1,\#I3,\#I13,\#I18,\#I20): “We need to make sure that GDPR does not hinder social and technological innovation, but foster data-driven innovation while making sure citizens' rights are respected. The competitive advantage of Europe in the future world of AI and data should be this 
rights-based democratic framework, a new deal on data that can shape a people-centric digital future and make GDPR an international standard" (See Table 3 and Appendix A).

\subsection{Experimentation within Grassroots Innovation Initiatives: "Decidim Barcelona"; and "Metadecidim Barcelona"}

According to Aragon et al. [101], Decidim Barcelona is an "online participatory-democracy platform launched by the City Council of Barcelona" (p. 277) on 1 February 2016 as the main grassroots innovation experimental strategic initiative [155]. In parallel fashion, Metadecidim Barcelona [156] was launched in November 2017 as a watchdog, technopolitical research community positioned to monitor Decidim Barcelona and reflect on its work. During its short tenure, Decidim Barcelona achieved the active participation of 40,000 citizens. Overall, 12 participatory processes were initiated and 11,873 proposals were analyzed, with $70 \%$ of proposals approved as public policy for a wide range of urban issues. Interviews revealed the difficulties of integrating representative participation from the private sector, particularly from large companies with a stake in city-making (\#I1,\#I2,\#I3,\#I13,\#I19,\#I20). Including the multi-stakeholders' framework suggests further challenges regarding representation and the constitution of socioeconomic co-operative firms and platforms beyond the civilian volunteer activist [157].

\subsection{Fostering Urban Co-Operative Platform Initiatives: "Digital Social Innovation", "Barcelona Urban Commons", and "Social Economy" Policy Framework}

The third identified experimental strategy centers around the emergence of three urban co-operative platform initiatives. According to Scholz [97], these initiatives "encompass new ownership models for the internet in the urban realm" (p. 1).

The first initiative, Digital Social Innovation [158], is an EU-funded project to map and support cases of digital social innovation in Europe [159]. In Barcelona, this initiative was established as the "Barcelona Maker District" around the FabLabs in the Poblenou neighbourhood. FabLabs aims to develop and expand new educational models and skills by democratizing access to fabrication through work with targeted segments, such as women, elderly people, and children.

Similarly, the second initiative, the Barcelona Urban Commons [160], was established in the broader metropolitan area of Barcelona in 2010 [161,162]. A wide range of economic activities affecting citizens and communities was identified, including "Guifi.net", "Som Energia", and "Coop57", among many others. Thus, over the last decade, these example activities offered digital connectivity, energy, and financial services, respectively, in a socioeconomic model that comprises $10 \%$ of the city economy. However, interviews revealed that some participants do not consider these initiatives as having successfully scaled up due to the shortcomings in transitioning from a grassroots communitarian movement driven by voluntarism to entrepreneurial co-operatives driven by professionalism (\#I1,\#I13).

The third initiative corresponds to the social economy policy framework which consists of 4718 socioeconomic projects and 861 co-operative firms [163]. This policy framework aims to support transformation of these projects from serving local economies to inclusion in the socioeconomic model of the entire city. My interviews point out the gap between the modus operandi of the corporate private sector and the initiatives conducted at the neighborhood level by the city council. One example is the recent launch of the new digital local currency called "rec", promoted by the EU-funded project B-Mincome [164], that addresses guaranteed minimum income in deprived urban areas of the city.

Despite the strong efforts of the council, the EU funds received to foster urban co-operative platforms, and the rapid pollination of projects, my findings suggest that the metropolitan ecosystem still needs to mature, particularly because scaling up an alternative socioeconomic model seems to be a process that takes longer than one institutional period. Although the strategic formulation attempts to line up a large number of initiatives in a transversal fashion, in the short term, it is likely to require further corrective measures. 
Table 3. Deconstructing Barcelona's (smart) citizen digital policy framework. GDPR—General Data Protection Regulation.

\begin{tabular}{|c|c|c|c|c|c|}
\hline \multirow{3}{*}{ Three Operational Research Questions } & \multirow{2}{*}{\multicolumn{3}{|c|}{ Policy Analysis }} & \multirow{3}{*}{$\begin{array}{l}\text { Scientific Analysis } \\
\text { Literature Review }\end{array}$} & \multirow{3}{*}{$\begin{array}{l}\text { Qualitative Analysis } \\
\begin{array}{l}\text { Based on twenty interviews of key stakeholders in Barcelona } \\
\text { from September } 2017 \text { to March } 2018\end{array} \\
\text { Summary of key responses structured through the Penta Helix } \\
\text { framework [34] (Appendix A): private sector (2); public sector (9); } \\
\text { academia (2); civic society (3); (social) entrepreneurs/activists (3). }\end{array}$} \\
\hline & & & & & \\
\hline & Experimental Strategies & & Strategic Initiatives & & \\
\hline $\begin{array}{l}\text { 1. What prospects exist for an alternative } \\
\text { data ownership regime in the ongoing } \\
\text { smart city model of Barcelona? } \\
\text { (\#E3) }\end{array}$ & $\begin{array}{l}\text { (Section 4.1.) } \\
\text { Data Ownership and } \\
\text { Technological Sovereignty }\end{array}$ & $\begin{array}{l}1 . \\
2 . \\
3 .\end{array}$ & $\begin{array}{l}\text { Barcelona Data Commons } \\
\text { City Data Analytics Office } \\
\text { Decode }\end{array}$ & {$[1,2,6,32,35,111,128-130,154]$} & $\begin{array}{l}\text { 1. The majority of interlocutors clearly addressed the positive and } \\
\text { irreversible transition as Barcelona is already adapting to the } \\
\text { GDPR (\#I7,\#I8,\#I9,\#I11,\#I14). } \\
\text { 2. The feedback was very positive in relation to the public } \\
\text { procurement reform (\#I20). } \\
\text { 3. The transition to open-source software presents remarkable } \\
\text { obstacles (\#I5,\#I6,\#I18). } \\
\text { 4. Despite the positive initiatives and irreversible transition } \\
\text { toward GDPR, Decode may have created overly high } \\
\text { expectations, as the initiative is perceived as "too experimental" } \\
\text { (\#I1,\#I2,\#I3,\#I15). }\end{array}$ \\
\hline $\begin{array}{l}\text { 2. What are the practical consequences of } \\
\text { the grassroots innovation initiatives } \\
\text { implemented in Barcelona for businesses, } \\
\text { local governments, academia, civic society, } \\
\text { and social entrepreneurs/activists? } \\
\text { (\#E2) }\end{array}$ & $\begin{array}{l}\text { (Section 4.2.) } \\
\text { Grassroots Innovations }\end{array}$ & $\begin{array}{l}1 . \\
2 .\end{array}$ & $\begin{array}{l}\text { Decidim Barcelona } \\
\text { Metadecidim Barcelona }\end{array}$ & {$[34,101,155,156]$} & $\begin{array}{l}\text { 1. Interlocutors argued that these initiatives lack an overall degree } \\
\text { of representation because they omit "stakeholders' power } \\
\text { relation interdependencies" (\#I19,\#I20). } \\
\text { 2. Others asked "How is the private sector represented in these } \\
\text { initiatives?" (\#I1,\#I2,\#I3,\#I13). } \\
\text { 3. The established channel could be seen as a seed to scale } \\
\text { up a broader deliberative governance model based on } \\
\text { "multi-stakeholder" representation (\#I12,\#I15,\#I16,\#I17). }\end{array}$ \\
\hline $\begin{array}{l}\text { 3. Is another experimental type of smart } \\
\text { city driven by co-operative service } \\
\text { provision models based on social } \\
\text { innovation possible in Barcelona? That is, } \\
\text { does a "third way" exist between the state } \\
\text { and the market that overcomes the PPP? } \\
\text { (\#E1) }\end{array}$ & $\begin{array}{l}\text { (Section 4.3.) } \\
\text { Urban } \\
\text { Co-Operative Platforms }\end{array}$ & $\begin{array}{l}1 . \\
2 .\end{array}$ & $\begin{array}{l}\text { Digital Social Innovation } \\
\text { Barcelona } \\
\text { Urban Commons } \\
\text { Social Economy }\end{array}$ & {$[2,97,116,132,159,161-164]$} & $\begin{array}{l}\text { 1. Interlocutors revealed the lack of a critical mass for } \\
\text { co-operative platforms (\#I4,\#II,\#II,\#I10,\#I20). } \\
\text { 2. Although Barcelona is shifting its smart-city model, } \\
\text { co-operative niche experiments are having difficulties scaling } \\
\text { up (\#I10,\#I16). } \\
\text { 3. Setting up a "third way" requires moving on from volunteer } \\
\text { grassroots initiatives to professional entrepreneurial } \\
\text { co-operatives (\#I1,\#I13). }\end{array}$ \\
\hline
\end{tabular}


To summarize this policy analysis and integrate it with the fieldwork research findings, Table 3 illustrates the responses to each research question proposed in this paper. The identified experimental strategies and the strategic initiatives respond directly to the initiatives that connect the three operational research questions. Despite the individual identification of initiatives, I must acknowledge the vast amalgamation of intertwined initiatives, confirmed through interviews, which made the fieldwork complex. Thus, Table 3 does not provide a deep analysis of each initiative but instead serves to deconstruct Barcelona's digital policy framework to examine strategic evidence-based insights by providing the main findings grouped through the coding system of interviews/interlocutors accordingly.

\section{Conclusions}

This paper's analysis of the current smart-city strategy and digital policy in Barcelona is exploratory and prospective because existing initiatives in Barcelona are new, with more awaiting implementation or existing only as concepts rather than material projects. Nonetheless, in light of the Barcelona study results, this paper argues that deconstructing the policy's framework provides further research directions to expand understanding of the ongoing urban challenges arising from the direct technopolitical implications of these initiatives for (smart) citizens. As a result, this paper concludes by highlighting these future research directions potentially shaped as follows: (i) post-GDPR privacy, technological sovereignty, and data commons alternative regimes in the establishment of more tailored, human-centered, and context-aware algorithmic governance platforms for new co-operative socio-economic models within and among European cities and regions; (ii) publicly scrutinized new bottom-up democratic mechanisms through blockchain infrastructure to conduct decentralized and networked decision-making and deliberation processes on integrated sectorial urban policies (energy, mobility, health, entrepreneurship, voting, taxation, residency, migration, etc.); (iii) practical urban experiments through living labs at the neighborhood and district level using blockchain technology to foster open social innovation ecosystems among a broad representation of agents through the Penta Helix multi-stakeholders' framework.

The research findings from the fieldwork (Appendix A) articulated (through interviews coded as \#I) and validated (through events coded as \#E) responses to the three operational research questions presented in the introduction, as summarized below.

In response to the first question (validated via \#E3), in the current experimental phase in Barcelona, the degree to which strategic initiatives modify technopolitical awareness of who owns data could offer interesting pathways for establishing an alternative data ownership regime. In addition, based on the fieldwork research findings, Barcelona City Council's new procurement process is designed to incentivize responsible innovation and respect for privacy, and is currently undergoing complete internal migration to open-source software by spring 2019. Furthermore, by the end of 2019, the city government plans to launch new online tools allowing people to selectively disclose the information they desire to share when using the council's official e-participation platform, Decidim Barcelona, while preserving citizens' anonymity. Nonetheless, the fieldwork revealed that, despite the positive transition reforming public procurement service provisions, technological sovereignty-citizens' ability to have a voice in surrounding technological infrastructure operation and end results-still has growth opportunities regarding integrating open-source software and emerging blockchain data architecture in the new EU context, characterized by the GDPR. As such, employing infrastructures such as blockchain is likely to require a new interpretation from the urban and data science perspective, which will be key to future experiments and predicting alternative data ownership regimes in cities. Likewise, technologies such as blockchain could improve access to data held by authorities while respecting privacy. Ultimately, this can also lead to proper evaluation of the ethical and political risks of smart cities with large databases by establishing a code of ethics for technological practices, including legal compliance with data protection regulations such as the GDPR and a defined data strategy benefitting citizens. 
In response to the second question (validated via \#E2), in light of the grassroots initiatives examined, interdependencies among stakeholders have a thorough policy focus while fostering ecosystems of entrepreneurial starts-ups and SMEs. However, despite the effort to bring together a wide range of stakeholders, interviews revealed that initiatives based on a collaborative, polycentric and deliberative governance model may need to evolve toward a more integrated, multi-stakeholder framework through further collaboration with the private sector (potentially by living labs bringing in entrepreneurial academics and enthusiastic civil servants). These initiatives might also need to foster the active role of social entrepreneurs, activists, "bricoleurs", brokers, and assemblers (see the fifth helix embedded in the Penta Helix multi-stakeholders' framework in Figure 1) to further explore the opportunities of an emerging and open social innovation ecosystem in Barcelona.

Ultimately, in response to the third question (validated via \#E1), thus far, PPPs were the leading smart-city model underpinning the alliance between the state and market in many cities. Yet, these deals may have been driven by neoliberal and extractivist data policy implementation. Questions such as "who controls the data?" are still rarely subject to any public oversight and scrutiny. Thus, to revert this situation, Barcelona could implement two steps: (i) build a critical mass of locally rooted co-operative platforms based on the data commons to scale-up initiatives, while taking back control of citizens' data; (ii) explore alternative, professional, entrepreneurial, co-operative business cultures to complement the volunteer grassroots seeds already flourishing $[157,165]$.

Regarding the lessons learnt from the Barcelona case study and policy implications of the field of interdisciplinary and global smart cities research [166], this paper, drawing from detailed policy analysis and fieldwork study, suggests that Barcelona, in the post-GDPR context, appears to be leading a cutting-edge digital transformation agenda that may soon influence other European or international cities and regions on data technopolitical implications for (smart) citizens.

Whereas, generally, the pervasive algorithmic disruption consciously or unwittingly reveals the lack of critical reflective smart-city policy-making, or indicates the hegemonic mainstreamed position of the PPPs, cities like Barcelona are challenging, and thus, embarked in experimenting an alternative policy route. Hence, it is likely the interdisciplinary and global smart cities research focus may gradually evolve toward the increasing study of a typology of (smart) citizens, defined as decision-makers and concerned users not only about data protection and security issues [167], but also data ownership and technological sovereignty policy implications directly related to digital rights to the city.

In summary, whether Barcelona's current strategy is little more than a declaration of intentions of a progressivist smart-city policy agenda remains to be seen. This paper concludes that, in the ongoing algorithmic disruptive context characterized by extractive data practices, smartness may not be appealing in cities such as Barcelona, although the experimental approach has yet to be firmly fixed as an alternative paradigm. Recognizing that smartness may not be appealing and having been viewed as technocratic, the experimental approach has yet to be entirely established. Thus, an open question remains: how will (smart) citizens decide, control, govern, manage, and ultimately, own their data by being both conscious of digital rights to the city and aware of duties in the technopolitical processes of city making?

Funding: The author's work was supported by the ESRC under the grant "Urban Transformations"; the RSA under grant "Smart City-Regional Governance for Sustainability" Research Network; the Brussels Centre for Urban Studies under the grant "Visiting Research Fellowship Scheme 2016"; and the European Commission under the Grant "H2020-SCC-01-2015-Smart Cities and Communities solutions integrating energy, transport, ICT sectors through lighthouse project-691735-REPLICATE".

Acknowledgments: The author is deeply indebted to the interlocutors/interviewees in Barcelona who kindly co-operated for interviews and data provision. I extend my gratitude also to Esteve Almirall and Ramón Sangüesa for help during the fieldwork research process in Catalonia.

Conflicts of Interest: The author declares no conflicts of interest. 
Appendix A. Lists of Interviews and Symposiums. The List of Interviewed Twenty Interlocutors Structured through Penta Helix Multi-Stakeholders' Framework [34] and the List of Three Symposiums Related to This Study during the Fieldwork Research from September 2017 to March 2018

Table A1. Details of direct sources: fieldwork research through interviews and symposiums from September 2017 to March 2018.

\begin{tabular}{|c|c|c|c|}
\hline & Interviews & & \\
\hline Interview/Interlocutor Coding System [168] & Description of the Stakeholder & Date & Penta Helix Multi-Stakeholders' Framework \\
\hline \#I1 & City Protocol Society & 4 September 2017 & \multirow{3}{*}{ Private sector } \\
\hline \#I2 & CISCO & 5 September 2017 & \\
\hline \#I3 & Telefónica Alpha & 6 September 2017 & \\
\hline$\# 14$ & Technology \& Digital Innovation Commissioner, Barcelona City Council & 7 September 2017 & \multirow{9}{*}{ Public sector } \\
\hline \#15 & Social Economy, Local Development and Consumption Commissioner, Barcelona City Council & 8 September 2017 & \\
\hline \#16 & Institut Municipal d'Informàtica (IMI), Barcelona City Council & 17 January 2018 & \\
\hline \#17 & Data Commons Program, Barcelona City Council & 19 March 2018 & \\
\hline \#18 & Municipal Data Office, Barcelona City Council & 20 March 2018 & \\
\hline$\# 19$ & General Secretary of Telecommunications, Cybersecurity, and Digital Society of the Regional Government of Catalonia & 21 March 2018 & \\
\hline \#110 & Democratic Innovation department, Barcelona City Council & 22 March 2018 & \\
\hline \#I11 & Smart Catalonia, Regional Government of Catalonia & 17 January 2018 & \\
\hline \#I12 & Digital Social Innovation department, Barcelona City Council & 17 January 2018 & \\
\hline \#I13 & ESADE Business School & 23 November 2017 & \multirow{2}{*}{ Academia } \\
\hline \#I14 & Universitat Pompeu Fabra (UPF) & 5 March 2018 & \\
\hline \#I15 & Urban Commons facilitator & 5 February 2018 & \multirow{3}{*}{ Civic society } \\
\hline \#I16 & Urban Co-operative representative & 6 February 2018 & \\
\hline \#I17 & Social Economy representative & 7 February 2018 & \\
\hline \#I18 & Technological activist & 8 February 2018 & \multirow{3}{*}{ (Social) entrepreneurs/activists } \\
\hline \#I19 & Algorithmic activist/entrepreneur & 9 February 2018 & \\
\hline \#I20 & Data scientist/entrepreneur & 12 February 2018 & \\
\hline \multicolumn{4}{|c|}{ Symposiums } \\
\hline Event Coding System [168] & Details of Each Symposium: Direct Participation with the Detailed Scientific Contribution & Date & Organizer \\
\hline \#E1 & $\begin{array}{l}\text { Smart City Expo World Congress } 2017 \text { (\#SCEWC2017) } \\
\text { Title: "Unplugging, Technopolitics of Data and Smart City Devolution: Comparing Barcelona, Bilbao, Glasgow, and Bristol" } \\
\text { (https:// www.igorcalzada.com/barcelona/) }\end{array}$ & 16 November 2017 & SCEWC \\
\hline \#E2 & $\begin{array}{l}\text { ESADE Smart Cities and Data Speaker Series (\#MIBASpeakerSeries) } \\
\text { Title: "Data Commons and Devolution in Europe: GDPR" } \\
\text { (https://www.igorcalzada.com/esade/ \& https:// www.youtube.com/watch?time_continue=6\&vV=iP8LVQWrdJ0) }\end{array}$ & 23 November 2017 & ESADE Business School \\
\hline \#Е3 & $\begin{array}{l}\text { Barcelona Data Commons program with the Board of Directors of the Barcelona City Council (\#DataCommons) } \\
\text { Title: "Cities \& Data: How the Digital, Big Data \& Data Science are Transforming the Government/Com el Digital, Big Data \& } \\
\text { Data Science esta Transformant els Governs" } \\
\text { (https: / / www.igorcalzada.com/speaker-on-the-board-of-directors-of-the-barcelona-city-council-on-data-driven- } \\
\text { cities-17-01-2018-catalonia-spain/) }\end{array}$ & 17 January 2018 & Barcelona City Council \\
\hline
\end{tabular}




\section{References}

1. Bria, F. Our Data Is Valuable. Here's How We Can Take That Value Back. 2018. Available online: https: / / www.theguardian.com/commentisfree/2018/apr/05/data-valuable-citizens-silicon-valley-barcelona (accessed on 5 April 2018).

2. Morozov, E.; Bria, F. Rethinking the Smart City: Democratizing Urban Technology; Rosa Luxemburg Stiftung: New York, NY, USA, 2018.

3. Xnet, Xnet installs a Whistleblowing Platform against Corruption for the City Hall of Barcelona-Powered by GlobaLeaks and TOR Friendly. 2017. Available online: https://blog.p2pfoundation.net/xnet-installswhistleblowing-platform-corruption-city-hall-barcelona-powered-globaleaks-tor-friendly /2017/01/19 (accessed on 27 July 2018).

4. Bass, T.; Sutherland, E.; Symons, T. Reclaiming the Smart City: Personal Data, Trust and the New Commons; NESTA: London, UK, 2018.

5. Andrews, J. How Will Europe's New Data Laws Affect Cities? 2018. Available online: https:/ / cities-today. com/how-will-europes-new-data-laws-affect-cities/ (accessed on 17 August 2018).

6. Barcelona City Council, Plan Digital de Ayuntamiento de Barcelona: Medida de Gobierno de Gestión Ética y Responsable de Datos: Barcelona Data Commons. 2018. Available online: http:/ / ajuntament.barcelona. $\mathrm{cat} /$ digital/en/blog/ethical-and-responsible-data-management-barcelona-data-commons (accessed on 31 March 2018).

7. General Data Protection Regulation (GDPR). 2018. Available online: https://www.eugdpr.org/ (accessed on 1 April 2018).

8. Edwards, L. Privacy, Security and Data Protection in Smart Cities: A Critical EU Law Perspective. Eur. Data Prot. Law Rev. 2016, 2, 28-58. Available online: https://papers.ssrn.com/sol3/papers.cfm?abstract_id= 2711290 (accessed on 17 August 2018). [CrossRef]

9. Schiek, D.; Gideon, A. Outsmarting the gig-economy through collective bargaining: EU competition law as a barrier to smart cities? Int. Rev. Law Comput. Technol. 2018, 32, 275-294. [CrossRef]

10. Bridle, J. New Dark Age; Verso: London, UK, 2018.

11. Finn, E. What Algorithms Want: Imagination in the Age of Computing; The MIT Press: Cambridge, MA, USA, 2017.

12. Van Dijck, J. Datafication, dataism and dataveillance: Big Data between scientific paradigm and ideology. Surveill. Soc. 2014, 12. [CrossRef]

13. Buttarelli, G. Big Tech Is Still Violating Your Privacy. 2018. Available online: https:/ /www.washingtonpost. com/news/theworldpost/wp/2018/08/14/gdpr/?utm_term=.9e9ddd6cf937 (accessed on 17 August 2018).

14. Evenstad, L. Cities Key to Making Data a New form of Infrastructure, Says Nesta. 2018. Available online: https: / / www.computerweekly.com/news/252445624/Cities-key-to-making-data-a-newform-of-infrastructure-says-Nesta (accessed on 17 August 2018).

15. Hintz, A.; Dencik, L.; Wahl-Jorgensen, K. Digital citizenship and surveillance society. Int. J. Commun. 2017, 11, 731-739.

16. O'Neill, C. Weapons of Math Destruction: How Big Data Increases Inequality and Threatens Democracy; Penguin Random House: London, UK, 2008.

17. Taplin, J. Move Fast and Break Things: How Facebook, Google, and Amazon Have Cornered Culture and What It Means for All of Us; Little Brown: New York, NY, USA, 2017.

18. Eubanks, V. Automating Inequality: How High-Tech Tools Profile, Police, and Punish the Poor; St. Martin's Press: New York, NY, USA, 2017.

19. Noble, S.U. Algorithms of Oppression: How Search Engines Reinforce Racism; NYU Press: New York, NY, USA, 2018.

20. European Commission. The Making of a Smart City: Policy Recommendations; European Commission: Brussels, Belgium, 2017.

21. European Commission. The Making of a Smart City: Best Practices across Europe; European Commission: Brussels, Belgium, 2017.

22. European Commission. The Making of a Smart City: Replication and Scale-Up of Innovation in Europe; European Commission: Brussels, Belgium, 2017.

23. Trencher, G. Towards the Smart City 2.0: Empirical Evidence of Using Smartness as a Tool for Tackling Social Challenges. Technol. Forecast. Soc. Chang. 2018. [CrossRef] 
24. Kitchin, R. The Data Revolution: Big Data, Open Data, Data Infrastructures \& Their Consequences; Sage: London, UK, 2014.

25. Karvonen, A.; Cugurullo, F.; Caprotti, F. Inside Smart Cities: Place, Politics and Urban Innovation; Routledge: London, UK, 2018.

26. Marvin, S.; Luque-Ayala, A.; McFarlane, C. Smart Urbanism: Utopian Vision or False Dawn? Routledge: New York, NY, USA, 2015.

27. Willis, K.S.; Aurigi, A. Digital and Smart Cities; Routledge: Oxon, UK, 2018.

28. Sadowski, J.; Pasquale, F. The Spectrum of Control: A social theory of the smart city. First Monday 2015, 20. [CrossRef]

29. Evans, J.; Karvonen, A.; Raven, R. The Experimental City; Routledge: London, UK, 2016.

30. Marvin, S.; Bulkeley, H.; Mai, L.; McCormick, K.; Palgan, Y.V. Urban Living Labs: Experimenting with City Futures; Routledge: London, UK, 2018.

31. Karvonen, A. The city of permanent experiments? In Innovating Climate Governance: Moving Beyond Experiments; Turnheim, B., Kivimaa, P., Berkhout, F., Eds.; Cambridge University Press: Cambridge, UK, 2018; pp. 201-215.

32. Barcelona City Council, Barcelona City Council Digital Plan 2017-2020: A Government Measure for Open Digitization: Free Software and Agile Development of Public Administration Services. 2017. Available online: http:/ / ajuntament.barcelona.cat/digital/en/blog/barcelona-digital-government-openagile-and-participatory (accessed on 31 March 2018).

33. Fielding, N.G. Triangulation and Mixed Methods Designs: Data Integration with New Research Technologies. J. Mixed Methods Res. 2012, 6, 124-126. [CrossRef]

34. Calzada, I.; Cowie, P. Beyond Data-Driven Smart City-Regions? Rethinking Stakeholder-Helixes Strategies. Regions 2017, 308, 25-28. [CrossRef]

35. Barcelona City Council, BITS, Barcelona Initiative for Technological Sovereignty. 2016. Available online: https:/ / bits.city/ (accessed on 10 December 2016).

36. Wallace, N.; Castro, D. The Impact of the EU's New Data Protection Regulation on AI; Centre for Data Innovation: Washington, DC, USA, 2018.

37. Chu, B. Angela Merkel at Davos. 2018. Available online: https://www.independent.co.uk/news/business/ analysis-and-features / angela-merkel-davos-2018-speech-trump-what-did-she-say-germany-a8176021. html (accessed on 10 March 2018).

38. Almirall, E.; Wareham, J.; Ratti, C.; Conesa, P.; Bria, F.; Gaviria, A.; Edmondson, A. Smart cities at the crossroads: New tensions in the city transformation. Calif. Manag. Rev. 2017, 59, 141-152. [CrossRef]

39. Caragliu, A.; Del Bo, C. The Economics of Smart City Policies. Sci. Reg. 2018, 17, 81-104.

40. Cardullo, P.; Kitchin, R. Being a 'Citizen' in the Smart City: Up and Down the Scaffold of Smart Citizen Participation in Dublin, Ireland. GeoJournal 2018, 78, 1-13. [CrossRef]

41. Christl, W.; Spiekermann, S. Networks of Control: Corporate Surveillance, Digital Tracking, Big Data and Privacy. 2016. Available online: http:/ / crackedlabs.org/dl/Christl_Spiekermann_Networks_Of_Control.pdf (accessed on 17 August 2018).

42. Christl, W. Corporate Surveillance in Everyday Life. How Companies Collect, Combine, Analyze, Trade, and Use Personal Data on Billions. A Report by Cracked Labs. 2017. Available online: http:/ / crackedlabs. org/en/corporate-surveillance/info (accessed on 17 August 2018).

43. Solon, O. Georges Soros: Facebook and Google a Menace to Society. 2018. Available online: https://www. theguardian.com/business/2018/jan/25/george-soros-facebook-and-google-are-a-menace-to-society (accessed on 26 February 2018).

44. Morozov, E. The Rise of Data and the Death of Politics. 2014. Available online: https://www.theguardian. com/technology /2014/jul/20/rise-of-data-death-of-politics-evgeny-morozov-algorithmic-regulation (accessed on 10 November 2016).

45. Morozov, E. So You Want to Switch Off Digitally? I'm Afraid That Will Cost You. 2017. Available online: https:/ / www.theguardian.com/commentisfree/2017/feb/19/right-to-disconnect-digitalgig-economy-evgeny-morozov (accessed on 19 March 2017).

46. Morozov, E. Capitalismo Big Tech ¿Welfare o Neofeudalismo Digital? Enclave de Libros Ediciones: Madrid, Spain, 2018. 
47. Stucke, E.; Grunes, A.P. Data-Opolies. 2017. Available online: https:/ /ssrn.com/abstract=9270180rhttp: / / dx.doi.org/10.2139/ssrn.2927018 (accessed on 3 March 2017).

48. Stucke, E. Should We Be Concerned About Data-Opolies? 2018. Available online: https://ssrn.com/ abstract $=3144045$ (accessed on 8 April 2018).

49. Bucher, T. Want to Be on Top? Algorithmic Power and the Threat of Invisibility on Facebook. New Media Soc. 2012, 14, 1164-1180. [CrossRef]

50. Cadwalladr, C.; Graham-Harrison, E. Revealed: 50 million Facebook Profiles Harvested for Cambridge Analytica in Major Data Breach. 2018. Available online: https:/ /www.theguardian.com/news/2018/mar/ 17/cambridge-analytica-facebook-influence-us-election (accessed on 19 March 2018).

51. Lupton, D. You Are Your Data: Self-Tracking Practices and Concepts of Data. In Lifelogging: Digital Self-Tracking and Lifelogging_Between Disruptive Technology and Cultural Transformation; Seike, S., Ed.; Springer: Wiesbaden, Germany, 2016; pp. 61-79.

52. Lupton, D.; Michael, M. Depends on Who's Got the Data: Public Understandings of Personal Digital Dataveillance. Surveill. Soc. 2017, 15, 254-268. [CrossRef]

53. Acuto, M. Global science for city policy. Science 2018, 359, 165-166. [CrossRef] [PubMed]

54. Coletta, C.; Kitchin, R. Algorithmic governance: Regulating the 'heartbeat' of a city using the Internet of Things. Big Data Soc. 2017, 4, 1-16. [CrossRef]

55. Danaher, J.; Hogan, M.J.; Noone, C.; Kennedy, R.; Behan, A.; De Paor, A.; Felzmann, H.; Haklay, M.; Khoo, S.M.; Morison, J.; et al. Algorithmic governance: Developing a research agenda through the power of collective intelligence. Big Data Soc. 2017, 4, 1-21. [CrossRef]

56. Calzada, I.; Cobo, C. Unplugging: Deconstructing the Smart City. J. Urban Technol. 2015, 22, 23-43. [CrossRef]

57. Nilssen, M. To the smart city and beyond? Developing a typology of smart urban innovation. Technological Forecast. Soc. Chang. 2018. [CrossRef]

58. Calzada, I. The Technopolitics of Data and Smart Devolution in City-Regions: Comparing Glasgow, Bristol, Barcelona, and Bilbao. Systems 2017, 5, 18. [CrossRef]

59. Joss, S. Future cities: Asserting public governance. Palgrave Commun. 2018, 4, 1-4. [CrossRef]

60. Shin, Y.; Shin, D. Modelling Community Resources and Communications Mapping for Strategic Inter-Organizational Problem Solving and Civic Engagement. J. Urban Technol. 2016, 23, 47-66. [CrossRef]

61. Shin, D. Ubiquitous city: Urban technologies, urban infrastructure and urban informatics. J. Inf. Sci. 2009, 35, 515-526. [CrossRef]

62. Thomas, V.; Wang, D.; Mullagh, L.; Dunn, N. Where's Wally? In Search of Citizen Perspectives on the Smart City. Sustainability 2016, 8, 207. [CrossRef]

63. Bulkeley, H.; Breitfuss, M.; Coenen, L.; Frantzeskaki, N.; Fuenfschilling, L.; Grillitsch, M.; Hartmann, C.; Kronsell, A.; McCormick, K.; Marvin, S.; et al. Working Paper on Urban living Labs and Urban Sustainability Transitions. GUST Governance of Urban Sustainability Transitions. 2015. Available online: http:/ / www.urbanlivinglabs.net/p/publications.html (accessed on 9 March 2018).

64. Evans, J. Trials and Tribulations: Problematizing the City through/as Urban Experimentation. Geogr. Compass 2016, 10, 429-443. [CrossRef]

65. Kronsell, A.; Mukhtar-Landgren, D. Experimental Governance: The Role of Municipalities in Urban Living Labs. Eur. Plan. Stud. 2018, 1-20. [CrossRef]

66. Scholl, C.; Kemp, R. City Labs as Vehicles for Innovation in Urban Planning Processes. Urban Plan. 2016, 1, 89-102. [CrossRef]

67. Schuurman, D.; De Marez, L.; Ballon, P. The Impact of Living Lab Methodology on Open Innovation Contributions and Outcomes. Technol. Innov. Manag. Rev. 2016, 1, 7-16. [CrossRef]

68. Almirall, E.; Wareham, J. Living labs: Arbiters of mid-and ground-level innovation. Technol. Anal. Strat. Manag. 2011, 23, 87-102. [CrossRef]

69. Von Wirth, T.; Fuenfschilling, L.; Frantzeskaki, N.; Coenen, L. Impacts of urban living labs on sustainability transitions: Mechanisms and strategies for systemic change through experimentation. Eur. Plan. Stud. 2018, 1-29. [CrossRef]

70. Mora, L.; Bolici, R.; Deakin, M. The First Two Decades of Smart-City Research: A Bibliometric Analysis. J. Urban Technol. 2017, 24, 3-27. [CrossRef] 
71. De Jong, M.; Joss, S.; Schraven, D.; Zhan, C.; Weijnen, M. Sustainable-smart-resilient-low carbon-eco-knowledge cities; making sense of a multitude of concepts promoting sustainable urbanization. J. Clean. Prod. 2015, 109, 25-38. [CrossRef]

72. Saunders, T.; Baeck, P. Rethinking Smart Cities from the Ground Up; NESTA: London, UK, 2015.

73. Kitchin, R. Reframing, Reimagining and Remaking Smart Cities. The Programmable City Working Paper 20. 2016. Available online: https:/ / osf.io/cyjhg/ (accessed on 7 February 2017).

74. Bull, R.; Azennoud, M. Smart citizens for smart cities: Participating in the future. Proc. Inst. Civ. Eng. Energy. 2016, 169, 93-101. [CrossRef]

75. Hemment, D.; Townsend, A. Smart Citizens; Future Everything Publications: Manchester, UK, 2013.

76. Noveck, B.S. Smart Citizens, Smarter State: The Technologies of Expertise and the Future of Governing; Harvard University Press: Cambridge, MA, USA, 2015.

77. Niederer, S.; Priester, R. Smart Citizens: Exploring the Tools of the Urban Bottom-Up Movement. Comput. Support. Cooperative Work (CSCW) 2016, 25, 137-152. [CrossRef]

78. Waag. A Manifesto for Smart Citizens. 2016. Available online: http://waag.org/en/blog/manifesto-smartcitizens (accessed on 20 December 2016).

79. Capdevilla, I.; Zarlenga, M. Smart City or Smart Citizens? The Barcelona Case. 2015. Available online: http:/ / dx.doi.org/10.2139/ssrn.2585682 (accessed on 7 July 2018).

80. Gutiérrez-Rubí, A. Smart Citizens: Ciudades a Escala Humana; Barcelona: Catalonia, Spain, 2017.

81. The Royal Society. Data Management and Use: Governance in the 21st Century; The Royal Society: London, UK, 2017.

82. Coletta, C.; Heaphy, L.; Perng, S.-Y.; Waller, L. Data-driven cities? Digital urbanism and its proxies: Introduction. Tecnoscienza Ital. J. Sci. Technol. Stud. 2017, 8, 5-18.

83. Burns, R.; Daltan, C.M.; Thatcher, J.E. Critical Data, Critical Technology in Theory and Practice. Prof. Geographer. 2018, 70, 126-128. [CrossRef]

84. Ojo, A.; Curry, E.; Zeleti, F.A. A Tale of Open Data Innovations in Five Smart Cities. In Proceedings of the 48th Hawaii International Conference on Systems Sciences, Kauai, HI, USA, 5-8 January 2015; pp. 2326-2335. [CrossRef]

85. Baeck, P. Data for Good: How Big and Open Data Can Be Used for the Common Good; NESTA: London, UK, 2015.

86. Gray, J.; Lämmerhirt, D. Data and The City: How Can Public Data Infrastructures Change Lives in Urban Regions; Open Knowledge: Cambridge, UK, 2017.

87. Harari, Y.N. Yuval Noah Harari on Big Data, Google and the End of Free Will. 2016. Available online: https:/ / www.ft.com/content/50bb4830-6a4c-11e6-ae5b-a7cc5dd5a28c (accessed on 10 November 2016).

88. Morozov, E.; Bria, F. Roundtable Session-A New Deal on Data: What Role for Cities? Smart City Expo World Congress. 2017. Available online: https:/ / www.youtube.com/watch?v=1cakaaip2Vw (accessed on 1 February 2017).

89. Shilton, K. When They Are Your Big Data: Participatory Data Practices as a Lens on Big Data. In Big Data is Not a Monolith; Sugimoto, C., Ekbia, H., Mattioli, M., Eds.; MIT Press: Boston, MA, USA, 2016.

90. PWC. From Concept to Applied Solutions: Data-Driven Cities; PWC: London, UK. 2016.

91. Ashton, P.; Weber, R.; Zook, M. The cloud, the crowd, and the city: How new data practices reconfigure urban governance. Big Data Soc. 2017, 4, 1-5. [CrossRef]

92. Kelleher, J.D.; Tierney, B. Data Science; The MIT Press: Cambridge, MA, USA, 2018.

93. Lohr, S. Data-ism: Inside the Big Data Revolution; Oneworld Publications: London, UK, 2015.

94. Acuto, M.; Steenmans, K.; Iwaszuk, E.; Ortega-Garza, L. Informing urban governance? Boundary-spanning organisations and the ecosystem of urban data. Area 2018, 1-10. [CrossRef]

95. Kitchin, R. Thinking critically about and researching algorithms. Inf. Commun. Soc. 2017, 20, 14-29. [CrossRef]

96. Gerlitz, C.; Helmond, A. The like economy: Social buttons and the data-intensive web. New Media Soc. 2013, 15, 1348-1365. [CrossRef]

97. Scholz, T. Platform Cooperativism: Challenging the Corporate Sharing Economy; Rosa Luxemburg Stiftung: New York, NY, USA, 2016.

98. Ostrom, E. Beyond Markets and States: Polycentric Governance of Complex Economic Systems. Am. Econ. Rev. 2010, 100, 1-33. [CrossRef]

99. Subirats, J.; Rendueles, C. Los Bienes Comunes ¿Oportunidad o Espejismo? Icaria: Barcelona, Spain, 2016. 
100. Hardin, G. The tragedy of the commons. Science 1968, 162, 1243-1248. [CrossRef] [PubMed]

101. Aragón, P.; Kaltenbrunner, A.; Calleja-López, A.; Pereira, A.; Monterde, A.; Barandiaran, X.; Gómez, V. Deliberative Platform Design: The Case Study of the Online Discussions in Decidim Barcelona. In Social Informatics; Ciampaglia, G.L., Mashhadi, A., Yasseri, T., Eds.; Springer International Publishing: Cham, UK, 2018.

102. Bianchi, I. The post-political meaning of the concept of commons: The regulation of the urban commons in Bologna. Space Polity 2018, 1-20. [CrossRef]

103. Alosi, A. Commoditized Workers: Case Study Research on Labor Law Issues Arising from a Set of on-Demand/Gig Economy Platforms. Comp. Labor Law Policy J. 2016, 37, 653.

104. Replicate EU Project: City-to-City-Learning Programme. 2018. Available online: www.replicate-project.eu (accessed on 18 August 2018).

105. Atkin, R. Stop Replacing London's Phone Boxes with Corporate Surveillance. 2018. Available online: https:/ / www.wired.co.uk/article/linkuk-bt-google-free-wifi-and-calls-london (accessed on 17 August 2018).

106. Cherry, M. Beyond misclassification: The digital transformation of work. Comp. Labour Law Policy Rev. 2016, $37,1-27$.

107. Levy, K.; Barocas, S. Refractive surveillance: Monitoring customers to manage workers. Int. J. Commun. 2018, 12, 1166-1188.

108. Andrews, L. I Know Who You Are and I Saw What You Did: Social Networks and the Death of Privacy; Free Press: New York, NY, USA, 2013.

109. Lightfoot, G.; Wisnieski, T.P. Information asymmetry and power in a surveillance society. Inf. Organ. 2014, 24, 214-235. [CrossRef]

110. Manzerolle, V.; Smeltzer, S. Consumer databases and the commercial mediation of identity: A medium theory analysis. Surveill. Soc. 2011, 8, 323-337. [CrossRef]

111. Jun, M. Blockchain government-A next form of infrastructure for the twenty-first century. J. Open Innov. Technol. Market Complex. 2018, 4, 1-7. [CrossRef]

112. Vanolo, A. Is there anybody out there? The place and role of citizens in tomorrow's smart cities. Futures 2016, 82, 26-36. [CrossRef]

113. De Waal, M.; Dignum, M. The citizen in the smart city. How the smart city could transform citizenship. Inf. Technol. 2017, 59, 263-273. [CrossRef]

114. Greenfield, A. Radical Technologies: The Design of Everyday Life; Verso: London, UK, 2017.

115. Hollands, R.G. Critical interventions into the corporate smart city. Camb. J. Reg. Econ. Soc. 2014, 8, 61-77. [CrossRef]

116. Calzada, I. From Smart Cities to Experimental Cities? In Co-Designing Economies in Transition: Radical Approaches in Dialogue with Contemplative Social Sciences; Giorgino, V.M.B., Walsh, Z.D., Eds.; Palgrave Macmillan: Cham, UK, 2018; pp. 191-217.

117. Arnstein, S.R. A ladder of citizen participation. J. Am. Inst. Plan. 1969, 35, 216-224. [CrossRef]

118. Kitchin, R. The Realtimeness of Smart Cities. Tecnoscienza Ital. J. Sci. Technol. Stud. 2017, 8, $19-41$.

119. Datacity Numa. 2018. Available online: http:/ / datacity.numa.co/ (accessed on 19 March 2018).

120. Campbell, T. Beyond Smart Cities: How Cities Network, Learn and Innovate; Earthscan: Oxon, UK, 2012.

121. Hajer, M.A.; Dassen, T. Smart about Cities: Visualising the Challenge for 21st Century Urbanism; Nai010 Publishers: Amsterdam, The Netherlands, 2014.

122. Mora, L.; Bolici, R. The Development Process of Smart City Strategies: The Case of Barcelona. In Proceedings of the 1st International City Regeneration Congress, Tampere, Finland, 3-4 September 2015.

123. Mora, L.; Bolici, R. How to Become a Smart City: Learning from Amsterdam. In Smart and Sustainable Planning for Cities and Regions: Results of SSPCR 2015; Bisello, A., Vettorato, D., Stephens, R., Elisei, P., Eds.; Springer International Publishing: Cham, UK, 2017; pp. 251-266.

124. Caprotti, F.; Cowley, R. Interrogating Urban Experiments. Urban Geogr. 2017, 38, 1441-1450. [CrossRef]

125. Decode (DEcentralised Citizens Owned Data Ecosystem). D.5.3. Data Analysis Methods and First Results from Pilots; Decode: Barcelona, Spain, 2018.

126. Sassen, S. Predatory Formations Dressed in Wall Street Suits and Algorithmic Math. Sci. Technol. Soc. 2017, 22, 6-20. [CrossRef]

127. March, H.; Ribera-Fumaz, R. Smart contradictions: The politics of making Barcelona a self-sufficient city. Eur. Urban Reg. Stud. 2016, 23, 816-830. [CrossRef] 
128. Barcelona City Council, Barcelona Ciutat Digital: A Roadmap Toward Technological Sovereignty. 2016. Available online: http://ajuntament.barcelona.cat/estaregiadigital/upload_Digital.pdf (accessed on 21 March 2018).

129. DEcentralised Citizens Owned Data Ecosystem (Decode). 2018. Available online: www.decodeproject.eu (accessed on 19 March 2018).

130. Roio, D. Algorithmic Sovereignty; University of Plymouth: Plymouth, UK, 2018.

131. Islar, M.; Irgil, E. Grassroots practices of citizenship and politicization in the urban: The case of right to the city initiatives in Barcelona. Citizsh. Stud. 2018, 22, 491-506. [CrossRef]

132. Mazzucato, M. The Entrepreneurial State: Debunking Public vs. Private Sector Myths; Public Affairs: New York, NY, USA, 2015.

133. Calzada, I. Problematizing and Politicizing Smart City-Regions: Is Devolution Smart? Territorio 2017, 83, 37-47. [CrossRef]

134. Eizaguirre, S. Comparing Social Innovation Initiatives in Barcelona and Bilbao. Looking at Associative Participation in the Governance of Citizens' Rights. Rev. Catal. Sociol. 2016, 31, 19-33. [CrossRef]

135. Blanco, I.; Salazar, Y.; Bianchi, I. Transforming Barcelona's Urban Model? Limits and Potentials for Radical Change under a Radical Left Government. 2017. Available online: http:/ /www.urbantransformations.ox.ac.uk/ blog/2017/transforming-barcelonas-urban-model-limits-and-potentials-for-radical-change-under-a-radicalleft-government/ (accessed on 19 March 2017).

136. Bollier, D. The City as a Commons. 2016. Available online: https:/ /www.youtube.com/wtch?v=z3itmhDuem8 (accessed on 1 February 2017).

137. Borch, C.; Kornberger, M. Urban Commons: Rethinking the City; Routledge: London, UK, 2015.

138. Foster, S.; Iaione, C. The City as a Commons. Yale Law Policy Rev. 2016, 34, 2. [CrossRef]

139. Rossi, U. The Variegated Economics and the Potential Politics of the Smart City. Territ. Politics Gov. 2016, 4, 337-353. [CrossRef]

140. Tõnurist, P.; Kattel, R.; Lember, V. Innovation Labs in the Public Sector: What They Are and What They Do? Public Manag. Rev. 2017, 19, 1455-1479. [CrossRef]

141. Bakıc1, T.; Almirall, E.; Wareham, J. A Smart City Initiative: The Case of Barcelona. J. Knowl. Econ. 2013, 4, 135-148. [CrossRef]

142. Degen, M.; García, M. The Transformation of the 'Barcelona Model': An Analysis of Culture, Urban Regeneration and Governance. Int. J. Urban Reg. Res. 2012, 36, 1022-1038. [CrossRef]

143. Gascó-Hernandez, M. Building a Smart City: Lessons from Barcelona. Commun. ACM 2018, 61, 50-57. [CrossRef]

144. Eizaguirre, S.; Parés, M. Communities making social change from below. Social innovation and democratic leadership in two disenfranchised neighbourhoods in Barcelona. Urban Res. Pract. 2018, 1-19. [CrossRef]

145. Tieman, R. Barcelona: Smart City Revolution in Progress. 2017. Available online: https://amp.ft.com/ content/6d2fe2a8-722c-11e7-93ff-99f383b09ff9 (accessed on 10 January 2018).

146. Jones, E. Smart City Barcelona. A City of the Future? 2015. Available online: http://www.barcelonametropolitan.com/features/smart-city-Barcelona/ (accessed on 21 March 2018).

147. Timeus, K.; Gascó, M. Increasing innovation capacity in city governments: Do innovation labs make a difference? J. Urban Affairs 2018. [CrossRef]

148. Morozov, E.; Harvey, D. Conversation between Evgeny Morozov and David Harvey. 2016. Available online: http:/ / davidharvey.org/2016/11/video-conversation-between-david-harvey-evgeny-morozov-on-postneoliberalism-trump-infrastructure-sharing-economy-smart-city/ (accessed on 10 November 2016).

149. Morozov, E.; Eno, B. Debat. Brian Eno i Evgeny Morozov Una Conversa Sobre Tecnologia i Democràcia. CCCB. 2017. Available online: https:/ / vimeo.com/206060710 (accessed on 28 February 2017).

150. Gartner. Gartner Says 8.4 Billion Connected “Things" Will Be in Use in 2017, up 31 Percept from 2016. 2017. Available online: https:/ /www.gartner.com/en/newsroom/press-releases/2017-02-07-gartner-says8-billion-connected-things-will-be-in-use-in-2017-up-31-percent-from-2016 (accessed on 20 August 2018).

151. Habermas, J. The Lure of Technocracy; Polity Press: New York, NY, USA, 2015.

152. Hughes, B. The Bleeding Edge: Why Technology Turns Toxic in an Unequal World; New Internationalist Publications Ltd:: Markham, ON, Canada, 2016.

153. Yin, R.K. Case study Research: Design and Methods; SAGE Publications: Thousand Oaks, CA, USA, 1984. 
154. Wiseman, J. Lessons from Leading CDOs: A Framework for Better Civic Analytics; Civic Analytics Network, Ash Centre for Democratic Governance and Innovation: Cambridge, MA, USA, 2017.

155. Decidim Barcelona. 2018. Available online: www.decidim.barcelona (accessed on 19 March 2018).

156. Metadecidim Barcelona. 2018. Available online: http://www.metadecidim.barcelona (accessed on 21 March 2018).

157. Mondragon Co-Operative Corporation. Mondragón del Futuro; MCC: Mondragon, Spain, 2018.

158. Digital Social Innovation. 2018. Available online: http:/ /ateneusdefabricacio.barcelona.cat/ (accessed on 19 March 2018).

159. Stokes, M.; Baeck, P.; Baker, T. What Next for Digital Social Innovation; NESTA: London, UK, 2017.

160. Barcelona Urban Commons. 2018. Available online: www.bcncomuns.net (accessed on 31 March 2018).

161. Observatorio Metropolitano de Barcelona, Comunes Urbanos de Barcelona. 2018. Available online: http:/ / www.bcncomuns.net (accessed on 21 March 2018).

162. Cámara, C. Urban Commons: Lessons from Barcelona at the Beginning of 21st Century; UOC: Barcelona, Spain, 2017.

163. Barcelona City Council, Plan de Impulso Economía Social y Solidaria. 2016. Available online: http:/ / ajuntament.barcelona.cat/economia-social-solidaria/es/objectivos-generales (accessed on 3 May 2018).

164. B-Mincome (Combining Guaranteed Minimum Income and Active Social Policies in Deprived Urban Areas). 2018. Available online: http:/ /www.uia-initiative.eu/en/uia-cities/barcelona (accessed on 19 March 2018).

165. Calzada, I. Knowledge Building \& Organizational Behaviour: Mondragon Case. In International Handbook of Social Innovation. Social Innovation: Collective action, Social Learning and Transdisciplinary Research; Moulaert, F., Maccallum, D., Mehmood, A., Hamdouch, A., Eds.; Edward Elgar Publishing: Cheltenham, UK, 2013; pp. 219-229.

166. Lytras, M.; Visvizi, A. Who Uses Smart City Services and What to Make of It: Toward Interdisciplinary Smart Cities Research. Sustainability 2018, 10, 1998. [CrossRef]

167. Visvizi, A.; Lytras, M. It's Not a Fad: Smart Cities and Smart Villages Research in European and Global Contexts. Sustainability 2018, 10, 2727. [CrossRef]

168. Campbell, J.L.; Quincy, C.; Osserman, J.; Pedersen, O.K. Coding in-depth semistructured interviews: Problems of unitization and intercoder reliability and agreement. Sociol. Methods Res. 2013, 42, 294-320. [CrossRef] 